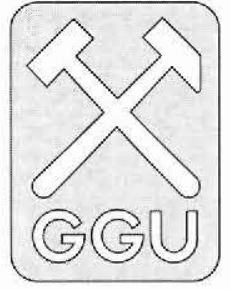

\title{
Sequence stratigraphic studies in the Jameson Land basin, East Greenland
}

\author{
S. Piasecki, F. Surlyk, F. Dalhoff, C. F. Hansen, \\ E. B. Koppelhus, N. Noe-Nygaard \\ and L. Stemmerik
}

A three-year research programme in Jameson Land was initiated in 1993 as part of ongoing studies of the postCaledonian sedimentary basins in East Greenland. The project is supported by the Danish Ministry of Energy and is carried out as a collaboration between the Geological Survey of Greenland (GGU) and Geological Institute, University of Copenhagen.

The purpose of the project is to examine the relationships between fluctuations in relative sea-level and the distribution of source- and reservoir rocks in the Upper Permian and Jurassic sedimentary succession in Jameson Land. The aim is to provide a framework for prediction of the hydrocarbon potential offshore East Greenland.

The overall depositional and stratigraphic patterns of the Upper Permian and Jurassic successions in Jameson Land are well known from numerous studies (see Surlyk, 1991; Surlyk et al., 1986; Stemmerik et al., 1993). During recent years detailed sedimentological studies have been carried out in the Lower Jurassic Kap Stewart and Neill Klinter Formations, the Middle Jurassic Vardekløft Formation and the Upper Jurassic Raukelv Formation (Dam, 1991; Dam \& Surlyk, 1992, 1993, in press; Engkilde \& Surlyk, 1993; Surlyk \& Noe-Nygaard, 1992; Surlyk et al., 1993). The 1993 field work, carried out by three field teams and one drilling team, continued these studies with sedimentological and stratigraphical investigations of selected units, which had been previously neglected or from which the available field and analytical data were not sufficient for the present study. In particular, the Jurassic organic-rich shales of the Sortehat and Hareelv Formations, the marine sandstones of the Upper Jurassic Raukelv Formation and the Upper Permian carbonate platform deposits at Karstryggen (Fig. 1) were investigated in detail.

\section{Jurassic sediments}

The Lower Jurassic Sortehat Formation is probably the least studied of the Jurassic units in Jameson Land. It is a shale dominated, brackish to marine deposited unit which so far has only been indirectly dated; it overlies Toarcian sandstones of the Neill Klinter Formation and is overlain by sandstones of the Vardekløft Formation with a Boreal Bajocian fauna. Sedimentological studies of the formation were carried out at Olympen and Trefjord Bjerg in northeastern Jameson Land, at the type locality Sortehat and along Neill Klinter in south-eastern Jameson Land (Fig. 1). The formation is separated from the underlying Neill Klinter Formation by an erosional surface. In the northern part of the area, the lower part of the formation is rather sandy. The content of sand gradually decreases southwards and in the southern part of the region the erosional surface is directly overlain by shales. The sedimentological investigations were supplemented by a detailed simpling programme of the Lower Jurassic succession to provide material for palynological investigations.

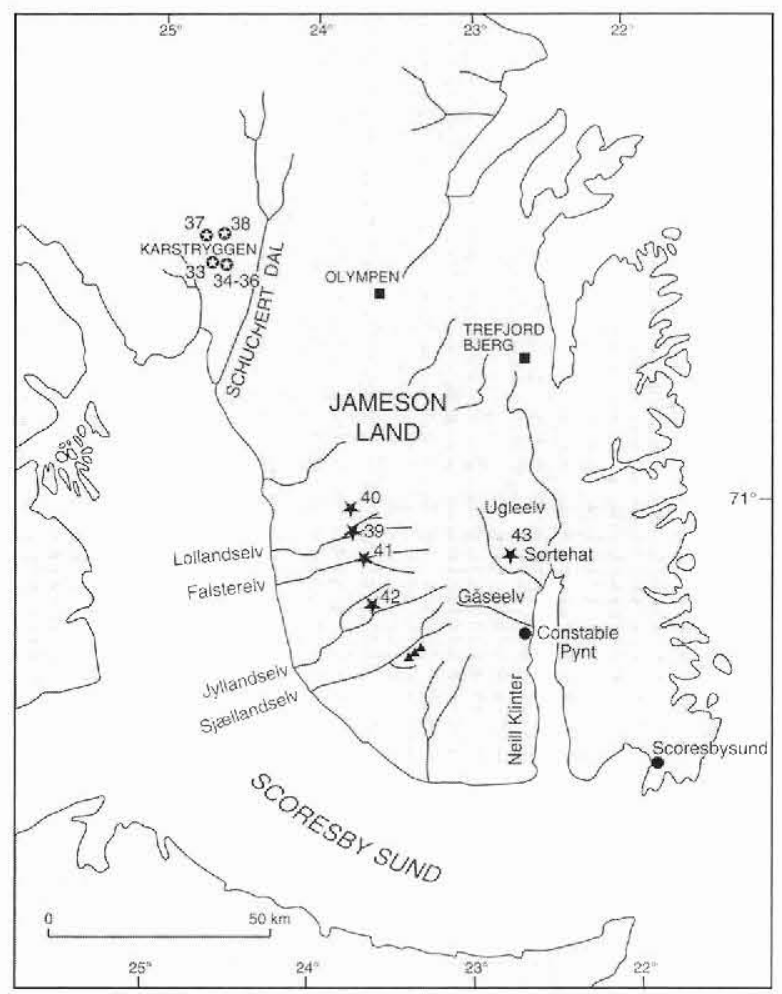

Fig. 1. Map of Jameson Land with main localities of fieldwork. Numbers 33-43 indicate location of the 1993 shallow core drill sites $303133-43$. The locality of the three older cores from Sjallandselv are indicated without numbers. 


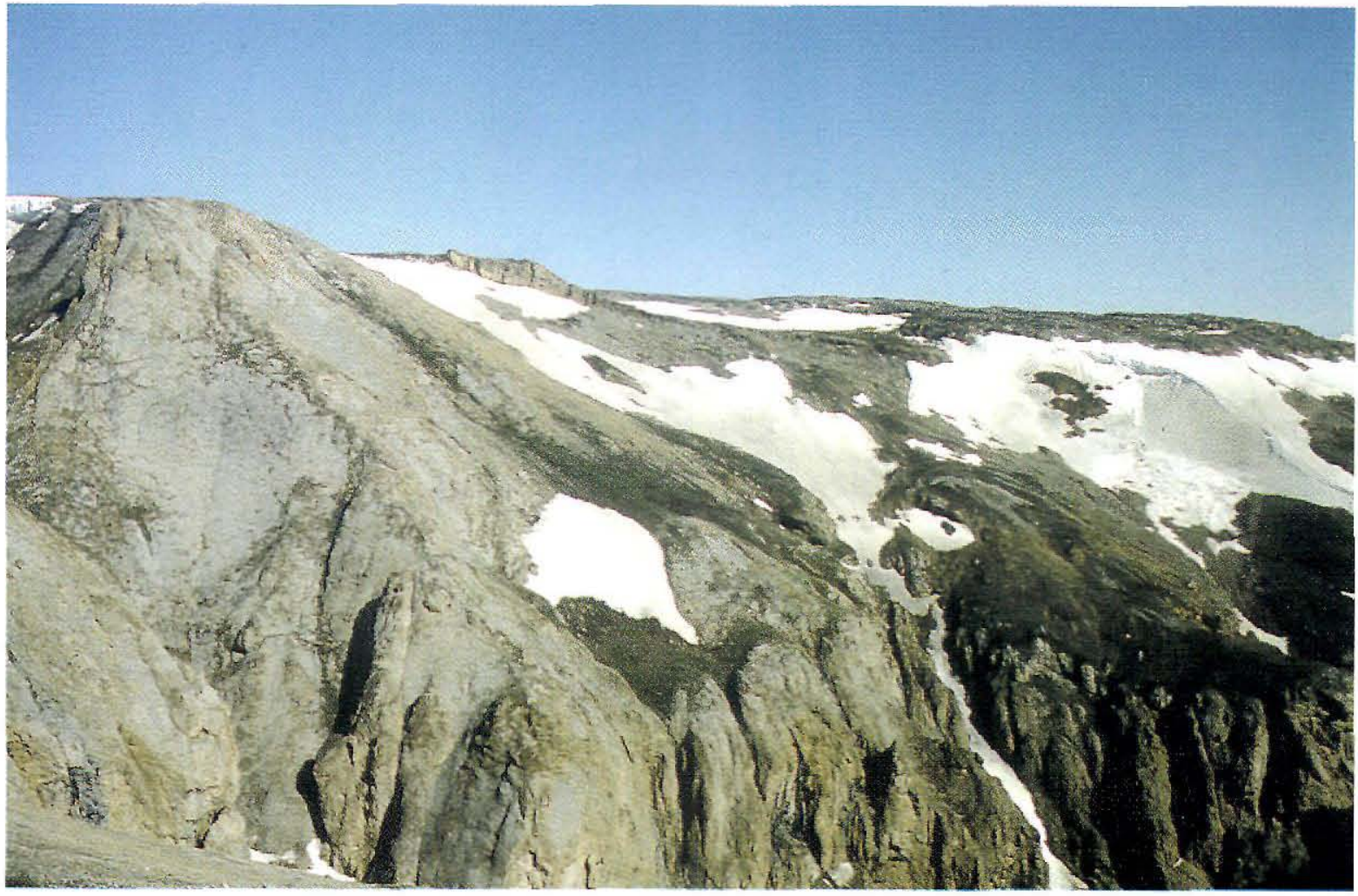

Fig. 2. Upper Permian carbonates on Karstryggen where fine-grained, marine carbonates onlap the topographic relief of the underlying karstified surface. The shallow cores 303134-36 were drilled as a transect from the margin and out in the basin at this locality.

In the Upper Jurassic Hareelv Formation field work focused on sedimentological investigations and sampling of macrofossils and material for palynological and geochemical analyses in the Sjællandselv, Gåseelv and Ugleelv areas (Fig. 1). Together with material from the shallow cores, samples cover the entire stratigraphic interval encompassed by the Hareelv Formation for the first time.

A detailed sedimentological and sequence stratigraphic study of the Fynselv Member (Raukelv Formation) was completed during the first half of the lield season. This member is characterised by a number of giant-scale crossbedded sandstone sheets which can be mapped out over an area of $900 \mathrm{~km}^{2}$. The sand sheets were deposited as laterally extensive flat-topped, tidally influenced sand banks with superimposed sandwave fields (Surlyk \& Noe-Nygaard, 1992). Special emphasis was placed on tying all sections together into a coherent stratigraphic system, and on the description and sequence stratigraphic interpretation of the key surfaces separating the individual sand bank units.

\section{Drilling programme}

The drilling programme was carried out with a helicopterportable unit operated with a wire-line system. The hole diameter was $4.6 \mathrm{~cm}$ and the core diameter $3.0 \mathrm{~cm}$.

A total of 11 holes (GGU 303133-43) were drilled to depths between $57 \mathrm{~m}$ and $102 \mathrm{~m}$ (average $85 \mathrm{~m}$ ) with a cumulative length of $932 \mathrm{~m}$ (Table 1). The cores were described at the drill site, small pieces of core from organicrich intervals were canned for analysis of light hydrocarbons and gamma ray logs were run (see Dalhoff, in press). The gamma ray logs appear to be particularly useful in the Jurassic where variations in the sand content of the shales are clearly reflected suggesting that the log-pattern can be used for environmental interpretation. Condensed intervals (maximum flooding surfaces) have not yet been clearly identified in the Jurassic shales on the basis of gamma ray logs.

The main aim of the drilling programme was to achieve information from inaccessible or poorly exposed intervals in the Upper Permian and Upper Jurassic successions. A single core was drilled through the Lower Jurassic Sortehat Formation to obtain fresh material for geochemical and sedimentological studies.

The first part of the drilling programme included six holes through the Upper Permian Wegener Halvø and Karstryggen Formations on Karstryggen. The cores form a transect from a shallow carbonate platform across the 


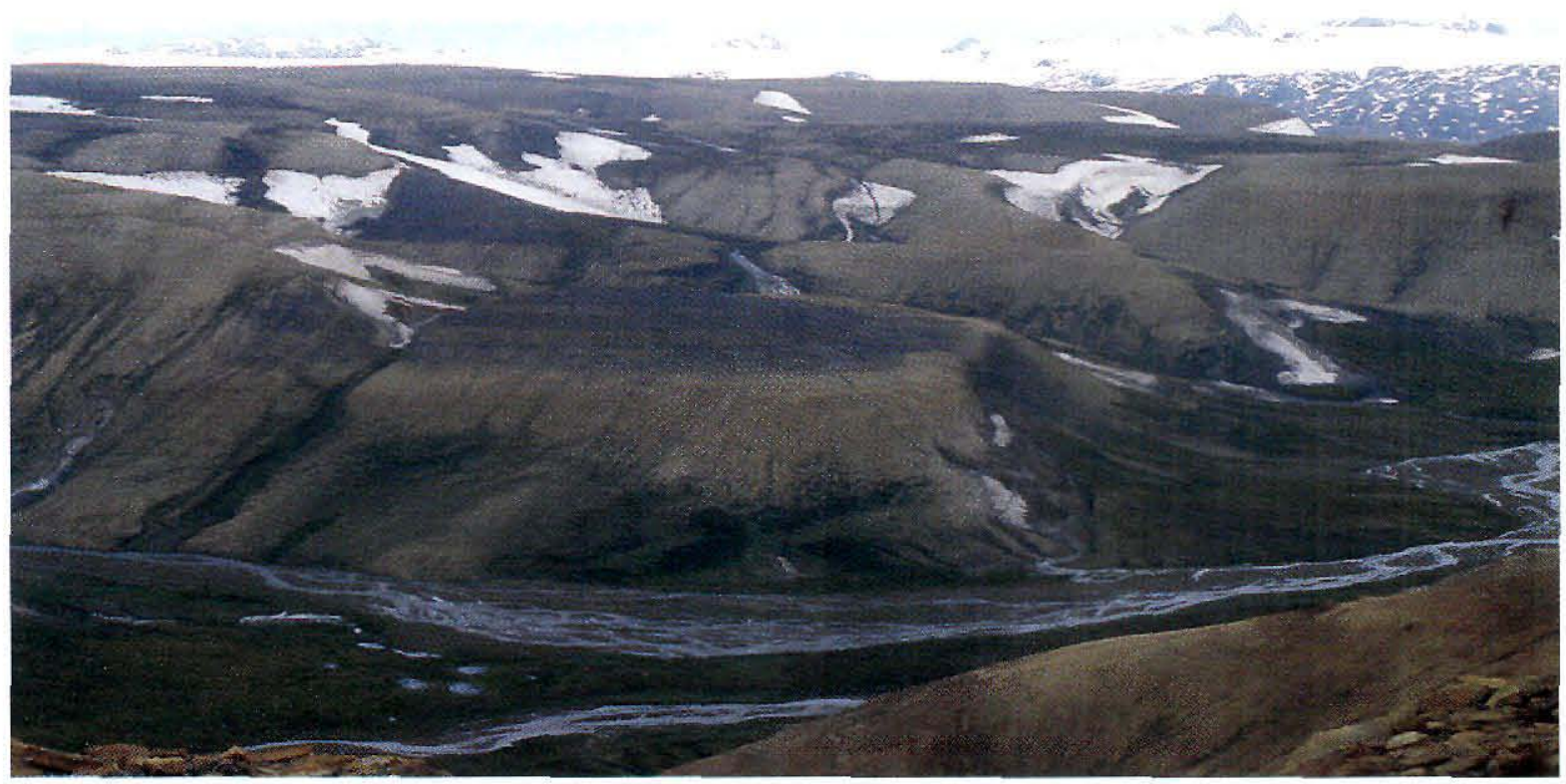

Fig. 3. Lower Jurassic Neill Klinter (light) and Sortehat (black) Formations at the locality Sortehat at Ugleelv, east Jameson Land. Shallow core 303143 was drilled here from the top of Sortehat down into the upper part of the Neill Klinter Formation.

Table 1. Shallow core drilling specifications for the holes drilled in 1993

\begin{tabular}{crrrrr}
\hline GGU & Date & Depth & Locality & Alt. & Stratigraphy \\
no. & \multicolumn{1}{c}{$\mathrm{m}$} & & $\mathrm{m}$ & \\
\hline 303133 & $8 / 7-10 / 7$ & 95.09 & Karstryggen & 725 & U. Permian \\
303134 & $12 / 7-13 / 7$ & 95.09 & Karstryggen & 750 & U. Permian \\
303135 & $16 / 7-17 / 7$ & 56.84 & Karstryggen & 735 & U. Permian \\
303136 & $19 / 7-20 / 7$ & 90.34 & Karstryggen & 620 & U. Permian \\
303137 & $22 / 7-23 / 7$ & 87.34 & Karstryggen & 900 & U. Permian \\
303138 & $25 / 7$ & 72.18 & Karstryggen & 830 & U. Permian \\
303139 & $29 / 7-04 / 8$ & 101.09 & Lollandselv & 80 & U. Jurassic \\
303140 & $6 / 8-07 / 8$ & 85.39 & Lollandselv & 140 & U. Jurassic \\
303141 & $10 / 8-11 / 8$ & 101.09 & Falsterselv & 84 & U. Jurassic \\
303142 & $14 / 8$ & 73.14 & Jyllandselv & 65 & U. Jurassic \\
303143 & $16 / 8-17 / 8$ & 74.27 & Sortehat & 274 & L. Jurassic \\
\hline
\end{tabular}

platform margin and into the proximal parts of the Upper Permian basin (Fig. 2) (see Surlyk et al., 1986; Piasecki \& Stemmerik, 1991; Stemmerik et al., 1990, 1993). These cores will form the basis for a detailed sequence stratigraphic study of the Upper Permian platform margin.

The second part of the drilling programme included four holes in the Upper Jurassic Hareelv Formation in western Jameson Land (Fig. 1). These cores show a transition from more proximal, sand-dominated to distal shaledominated parts of the Late Jurassic basin. These cores, together with three cores drilled in 1983 (GGU 303114-16) at Sjællandselv are assumed to form an almost complete composite section through the Hareelv Formation. The cores thus provide important additional material for biostratigraphical, sedimentological and organic geochemical analyses of these organic-rich shales. The last part of the drilling programme was a core through the lower part of the Sortehat Formation and the top $20 \mathrm{~m}$ of the Neill Klinter Formation (Fig. 3)

\section{Future studies}

Laboratory work will concentrate on palynostratigraphical studies and geochemical analyses of shales. These results will be integrated with sedimentological data in order to refine the sequence stratigraphic models for the Upper Permian and Jurassic successions in the area, and particularly to increase understanding of the stratigraphical and spatial distribution of potential source rocks and reservoir rocks. Supplementary field work in the Lower 
Jurassic succession for one field-team is planned for the 1994 season.

Acknowledgements. The Project was financed by the Energy Research Programme (EFP-93; 1313/93-0010) of the Danish Ministry of Energy.

The sedimentological studies of the Sortehat Formation were carried out as a Ph.D. project at the University of Copenhagen (C.F.H.), and the palynostratigraphical investigations of the Lower Jurassic sediments form part of a post-doctorate project at GGU (E.B.K.).

\section{References}

Dalhoff, F. in press: Shallow core summary sheets: Upper Permian of Karstryggen Formation. Open File Series, Gronlands geol. Unders.

Dam, G. 1991: A sedimentological analysis of the continental and shallow marine Upper Triassic to Lower Jurassic succession in Jameson Land, East Greenland. Unpublished Ph.D. thesis, University of Copenhagen, 243 pp.

Dam, G. \& Surlyk, F. 1992: Forced regressions in a large wave and storm-dominated anoxic lake, Rhaetian-Sinemurian Kap Stewart Formation, East Greenland. Geology 20, 749-752.

Dam, G. \& Surlyk, F. 1993: Cyclic sedimentation in a large wave and storm-dominated anoxic lake; Kap Stewart Formation (Rhaetian - Sinemurian), Jameson Land, East Greenland. In Possamentier, H. W., Summerhayes, C. P., Haq, B. U. \& Allen, G. P. (ed.) Sequence stratigraphy and facies associations. Int. Ass. Sediment. Spec. Publ. 18, 419-448.

Dam, G. \& Surlyk, F. in press: Sequence stratigraphic correlation of Lower Jurassic shallow marine and paralic successions across the Greenland-Norway Seaway. In Steel, R. J. et al. (ed.) Sequence stratigraphy of NW European margin. Spec. Publ. Norwegian Petrol. Soc. Amsterdam: Elsevier.

Engkilde, M. \& Surlyk, F. 1993: The Middle Jurassic Vardekløft Formation of East Greenland - analogue for reservoir units of the Norwegian shelf and the northern North Sea. In Parker, J. R. (ed.) Petroleum geology of Northwest Europe: Proceedings of the 4th conference, 533-542. London: Geological Society.

Piasecki, S. \& Stemmerik, L. 1991: Late Permian anoxia in central East Greenland. In Tyson, R. V. \& Pearson, T. H. (ed.)
Modern and ancient continental shelf anoxia. Spec. Publ. Geol. Soc. Lond. 58, 275-290.

Stemmerik, L., Scholle, P. A., Henk, F. H., Di Liegro, G., Mantovani, M. \& Ulmer, D.S. 1990: Facies mapping and reservoir evaluation of the Upper Permian Wegener Halvø Formation along the western margin of the Jameson Land basin, East Greenland. Rapp. Grønlands geol. Unders. 148, 105-108.

Stemmerik, L., Scholle, P. A., Henk, F. H., Di Liegro, G. \& Ulmer, D. S. 1993: Sedimentology and diagenesis of the Upper Permian Wegener Halvø Formation carbonates along the margins of the Jameson Land Basin, East Greenland. In Vorren, T. O. et al. (ed.) Arctic geology and petroleum potential. Spec. Publ. Norwegian Petrol. Society 2, 107-119. Amsterdam: Elsevier.

Surlyk, F. 1991: Sequence stratigraphy of the Jurassic - lowermost Cretaceous of East Greenland. Bull. Amer. Ass. Petrol. Geol. $75,1468-1488$.

Surlyk, F. \& Noe-Nygaard, N. 1992: Sand bank and dune facies architecture of a wide intracratonic seaway: Late Jurassic Early Cretaceous Raukelv Formation, Jameson Land, East Greenland. In Miall, A. D. \& Tyler, N. (ed.) The three-dimensional facies architecture of terrigenous clastic sediments, and its implication for hydrocarbon discovery and recovery. SEPM (Society for Sedimentary Geology), Concepts in Sedimentology and Paleontology 3, 261-276.

Surlyk, F., Hurst, J. M., Piasecki, S., Rolle, F., Scholle, P. A., Stemmerik, L. \& Thomsen, E. 1986: The Permian of the western margin of the Greenland Sea - A future exploration target. In Halbouty, M. T. (ed.) Future petroleum provinces of the world. Mem. Amer. Ass. Petrol. Geol. 40, 629-659.

Surlyk, F., Noe-Nygaard, N. \& Dam, G. 1993: High and low resolution sequence stratigraphy in lithological prediction examples from the Mesozoic around the northern North Atlantic. In Parker, J. R. (ed.) Petroleum geology of Northwest Europe: Proceedings of the 4th conference, 199-214. London: Geological Society.

S. P., F. D., E. B. K. \& L. S., Geological Survey of Greenland, Copenhagen

F. S., C. F. H. \& N. N.-N., Geological Institute, Øster Voldgade 10, DK-1350 Copenhagen K, Denmark 